\title{
ТЕОРЕТИЧНІ ЗАСАДИ ВИКОРИСТАННЯ МЕТОДОЛОГІЇ ФОРСАЙТУ У ПЕРЕДБАЧЕННІ РОЗВИТКУ ПРОМИСЛОВИХ ПІДПРИЕМСТВ
}

\section{ТЕОРЕТИЧЕСКИЕ ОСНОВЫ ИСПОЛЬЗОВАНИЯ МЕТОДОЛОГИИ ФОРСАЙТА В ПРЕДВИДЕНИИ РАЗВИТИЯ ПРОМЫШЛЕННЫХ ПРЕДПРИЯТИЙ}

\author{
THEORETICAL FOUNDATIONSFOR THE USING OF THE FORESIGHT \\ METHODOLOGY IN PREDICTING OF INDUSTRIAL ENTERPRISES DEVELOPMENT
}

\begin{abstract}
Описано передумови виникнення і розвитку методологї Форсайту. Проаналізовано ретроспективу розвитку технологічного передбачення. Визначені обмеження практичного застосування існуючих підходів. Окреслено проблематику передбачення з врахуванням можливості використання якісних та кількісних методів. Виокремлено мету дослідження, яка обмежується передбаченнями розвитку промислових підприємств. Описано комплекс методик, щз залучаються до формування засад Форсайту, а саме методу Делфі та SWOTаналізу. Розкрито процедури роботи експертів $i$ етапів проведення SWOT-аналізу. Запропоновано інструментарій методології Форсайту з використанням об'єктивних $i$ суб'єктивних очінок. Описано конщептуальні засади, комплекс робіт і процедуру розробки сценарії розвитку на основі піраміди А. Аткіссона (комплекс робіт з передбачення). Здійснено висновки за проведеним дослідженням. Запропоновано напрями подальших досліджень з проблематики Форсайту.
\end{abstract} Аткіссона

Ключові слова: Форсайт, передбачення, промислові підприємства, піраміда

Описаны предпосылки возникновения и развития методологии Форсайта. Проанализированы ретроспективы развития технологического предвидения. Определены ограничения практического применение существующих подходов. Определена проблематика предвидения с учетом возможности использования качественных и количественных методов. Выделена иель исследования, которая ограничивается предвидением развития промышленных предприятий. Описан комплекс методик, используемых в формировании основ Форсайта, а именно метод Дельфи и SWOT-анализ. Раскрыто процедуры работь экспертов и этапов проведения SWOT-анализа. Предложен инструментарий методологии Форсайта с использованием объективных и субъективных оценок. Описаны конщептуальные основы, комплекс работ и процедура разработки сценариев развития на основе пирамиды А. Аткиссона (комплекс работ по предвидению). Сделаны выводы по проведенному исследованию. Предложены направления дальнейших исследований по проблематике Форсайта.

Ключевые слова: Форсайт, предвидение, промышленные предприятия, пирамидаАткиссона

We have described the background of the development of methodologies and Foresight as well as made the analysis of technological insight retrospective. The limit of the practical application of existing approaches was also defined. Also we have outlined the issues with regard to predicting the possibility of using qualitative and quantitative methods. Furthermore we have determined the study purposes which are limited to predictions of industrial enterprises development. We have described the complex of techniques involved in the formulation of the Foresight principles, namely Delphi method and SWOT-analysis. What is more, we have cleared up the procedures of experts work and stages of SWOT-analysis the same as provided the strong factors of Ukrainian power industry. We ve suggested a Foresight toolkit methodology using 
objective and subjective assessments. In addition we ve described the conceptual framework, a set of works and procedure formulation scenarios of the development based on A. Atkisson's pyramid (works on predictions). The conclusions have been eventually made as well as the prospective of the further research directions on the problems of Foresight were defined.

Keywords: Foresight, prediction, industrial enterprises, Atkisson's Pyramid

Вступ. Для формування картини майбутнього використовується методологія Форсайту (або передбачення) [1]. Ця методологія дає можливість представити майбутнє об'єкту, яке не можна змоделювати як екстраполяцію минулого на певний відтинок часу. Зазначене пов'язано з тим, що це майбутнє набуває принципово нової форми та суті. Передбачення, тобто певною мірою визначення вихідних даних для планування стратегічних змін інноваційного розвитку підприємств певної галузі на систематичній основі розпочалося наприкінці 1980-х років, коли економічні аналітики почали займатися інноваційними системи. Отже, для планів стратегічних змін розвитку підприємств у розвинених країнах (насамперед, Великобританії, Німеччині, США, Франції, Японії) активно почала використовуватися методологія Форсайт (переклад 3 англ. foresight - передбачення). На сьогодні Форсайт зарекомендував себе як досить ефективний інструментарій для визначення пріоритетів у галузевому розвитку. Загалом, Форсайт - це систематизовані методичні підходи у передбаченні середньо- та довгострокового майбутнього певної предметної сфери, що ставить за мету визначення певних зон зміни параметрів, які у кінцевому результаті дадуть вигоди.

Звичайно, не існує універсальних підходів до вирішення проблематики передбачення. Як правило, існуючі методики використовують інструментарій, що базується переважно на якісних методах. Так, як передбачення - це комплекс робіт, що базується на поєднанні експертних знань та інструментарію, алгоритмів і методів. Слід зазначити, що системний аналіз можна вважати універсальною методологією для проведення передбачення. У такому випадку виникає необхідність виокремлення кожного елементу та опису взаємозв'язків у системі. Поєднання методів, наприклад, Делфі та SWOTаналізу, розширює можливості передбачення. Подібні дослідження були здійснені на рівнях країни, регіону, галузі, технології та описані в роботах Н. В. Гапоненка[2], В. В. Масленникова, А. Н. Шмелевої[3],Т. К. Кваші А. Л. Кушнира[4]. Проте досить значний пласт проблем у цих роботах не вирішено.

Постановка завдання. За мету ставиться формування засад до використання Форсайту у передбаченні розвитку промислових підприємств. Задачами наукового пошуку є побудова інструментарію для якісного сценарію функціонування цих підприємств у середньо- та довгостроковому майбутньому. Концептуальні положення методології Форсайту передбачають використання об'єктивних і суб'єктивних оцінок (насамперед, за допомогою експертів) та методу Делфі (бальна оцінка). Саме за методом Делфі пропонується сформувати послідовність його реалізації для промислових підприємств. А основу комплексу робіт становитиме побудова піраміди, яка запропонована А. Аткіссоном. 
Методологія. 3 врахуванням особливостей предмету дослідження пропонується використовувати системну методологію передбачення, яка 3 метою формування бачення можливого майбутнього в будь-якій галузі застосовує методологію Форсайту. Поряд 3 цим використовуються експертні методи, системний аналіз, поєднання таких методів як Делфі та SWOT-аналіз.

Результати дослідження. 3 метою побудови якісного сценарію слід визначитися та вдало використати конкурентні переваги сфери діяльності, яку досліджуємо. Саме враховуючи особливості предмету дослідження нами використано методологію передбачення, яка у результаті формує бачення можливого майбутнього виробничо-комерційної діяльності підприємств на основі форсайту. Концептуальні положення цієї методології надають можливість представити майбутнє, яке не може бути повною мірою інтерпретоване як звичайне продовження минулого (екстраполяція трендів). Приймаємо те, що це майбутнє у зв'язку 3 певними суттєвими змінами в техніці, технології, економіці чи у політиці набуває принципово нової структури.

Передбачення ставить за необхідність, базуючись на об'єктивних i суб'єктивних оцінках, створювати сценарії майбутніх подій на короткостроковому, середньостроковому та довгостроковому відтинку часу. Розмежування на часові відтинки потрібне для побудови певної групи сценаріїв та формування оптимальної за певних умов стратегії розвитку галузі.

Ретроспектива розвитку технологічного передбаченняпоказує, що спочатку для цього використовувалисятрадиційні методи математичної обробки інформації та статистичні методи. Згодом було створено методики, що базувалися на часових рядах, на регресійному аналізу, на імітаційному моделюванню, а також різні економетричні моделі. Як правило, таке передбачення майбутнього визначає поведінку певних параметрів системи (показників, індикаторів, індексів) на певному часовому інтервалі.

Проте ці методи мають обмежене практичне застосування, що пов'язано 3 обмеженнями, до яких належать суттєві, різки зміни у техніці та технології, форс-мажорні обставини державного та наднаціонального рівнів. У такому випадку звичайна ретроспектива даних не дає повної картини майбутнього, адже відсутні подібні факти у минулому. У такому випадку екстраполяція може досить приблизно відображати можливу реальність. Ця обставина суттєво обмежує можливості використання класичних методів, що побудовані на основі екстраполяції даних. Варто зазначити, що саме на фазі зміни технологічних укладів ці методи не можуть надати адекватні сценарії розвитку сфери діяльності. Сьогодні ми маємо стрибкоподібні зміни, практична відсутність монотонних процесів i характеризуються нелінійними функціональними залежностями.

На початковому етапі експертами визначається структура промислової інфраструктури (як правило, визначаються числові значення основних показників, співвідношення складових тощо), яка буде відповідати поставленим середньо- та довгостроковим цілям дослідження. Форсайт інфраструктури майбутньої сфери діяльності промислових підприємств здійснюватиметься 
методом Делфі. Основою є висновок групи експертів про поведінку (зміну) характеристик досліджуваної системи. Отримані результати за обробкою експертного опитування у подальшому будуть використовуватися для побудови можливих сценаріїв. Слід зазначити, що для спрощення роботи експертів розробляються опитувальні форми - спеціальні таблиці, що адаптовані для вирішення завдань експертизи.

3 метою проведення аналізу на середньо- та довгострокову перспективи розроблюються різні форми, хоча вони можуть мати окремі спільні частини. Форми, як правило, у вигляді таблиць мають містити як описову частину, так і числову оцінку тих параметрів, які описуються. При можливості приводяться реальні числові значення тих показників, які описуються, а при неможливості чи ускладненні допустимою є використанням бальної оцінки.

За методом Делфі здійснюється наступна послідовність:

1) підбір групи експертів, що належним чином володіють предметом експертизи чи рівень їх знань з проблематики належний;

2) формулювання мети, яку маємо намір досягти у результаті вирішення проблематики;

3) розробка опитувальної форми (як правило, у вигляді таблиці);

4) опитування групи експертів (використовується розроблена форма);

5) використання математичного апарату статистичної обробки даних опитування (результатом є нові знання з проблематики передбачення);

6) аналіз кожним експертом отриманих і оброблених результатів, а також опрацювання думок усіх експертів і висновків усієї групи;

7) при виникненні у експерта бажання скорегувати свої дані (як правило, таке трапляється після обробки всіх форм, що пов'язано з появою нових знань і ці знання дещо змінюють існуючі погляди на проблематику експерта). У такому випадку здійснюється повторна обробка даних згідно до пункту 5.

8) пункти від 5 до 7 виконуються до тих пір, поки всі експерти не перестануть коригувати свої форми. В окремих випадках після багаторазового виконання пунктів 5-7 у відповідях експертів не досягається консенсусу. зазначене свідчить про наступне: 1) неможливо розв'язати проблематику; 2) дещо не вдалий підбір експертів; 3) не вірно використано методику. У такому випадку варто повторити етапи, починаючи з першого.

9) група експертів приймають консенсусне рішення шляхом колективного аналізу отриманих і оброблених даних

10) узагальнення результатів та їх інтерпретація.

Проведення більш глибокого дослідження потребує використання SWOTаналізу. Експертами виділяється низка факторів, які суттєво впливають на об'єкт дослідження. Окремо виділяємо фактори (чи індикатори), які представляють сильні, слабкі фактори розвитку підприємницької сфери, а також можливості та загрози для іiі подальшого розвитку. Варто формувати окремі таблиці для середньо- та довгострокової перспектив. Як і в попередній методиці за методом Делфі, слід використовувати не тільки якісну оцінку факторів, а й приводити числові значення тих показників, що характеризують той чи інший фактор. 
Подальша пошукова робота має містити процедуру розробки сценаріїв розвитку промислових підприємств. Сценарії також можуть розроблятися на коротко- та довгострокову перспективи. У нашому випадку доцільно взяти середньостроковий сценарій з обмеженням часового періоду 2020 роком, а довгостроковий - 2030 роком. Системність дослідження потребує зважання на те, що будь-яка підприємницька сферає не тільки галузь економіки, а й сфера, яка певним чином впливає на навколишнє середовище. До того ж продукти промисловості забезпечують належний рівень життя Людини, тобто високий рівень якості та безпеки життя. Саме останнє входить до концептуальних засад сталого розвитку. У такому випадку доцільно використовувати основні положення цієї концепції. Зазначимо, що такими є гармонійне поєднання економічної, екологічної та соціальної складових. Концептуальні положення також передбачають розмежовувати індекс якості життя та індекс безпеки життя. Вагомими дослідженнями займався А. Аткіссон [5], який окрім екологічного (nature), економічного (economy), соціального (society) виміру, використовує розумний розвиток (wellbeing).

Положення сталого розвитку та концептуальні засади, що розроблені А. Аткіссоном, надають основу для формування концептуальних засад методики передбачення для промислових підприємств України. Основними положеннями цього інструментарію є виконання наступних етапів:

1) визначення показників, які суттєво визначають теперішній стан промисловості та показників, які на думку експертів можуть визначати подальший розвиток підприємств на середньо- та довгострокову перспективи;

2) групування показників за елементами впливу (економічні, екологічні, соціальні);

3) створення карти взаємозв'язків у системі;

4) системний аналіз і візуалізація результатів аналізу;

5) експертне опитування про стан та перспективи розвитку промислових підприємств;

6) обробка результатів експертизи;

7) формування сценаріїв розвитку промислових підприємств України.

Комплексом робіт також передбачається здійснення поступової побудови піраміди (рисунок). Основу формування обрано за А. Аткіссоном, використано також його підхід до назв рівнів піраміди. Послідовністю реалізації положень $\epsilon$ наступна (англомовні позначення для 1-4 етапів запозичені в положеннях, що розроблені А. Аткіссоном, 5 - запропоновано нами):

1) I (indexes) - Формування структури показників, що характеризують сферу діяльності;

2) S (system) - Створення карти системи, формування матриць, визначення зв'язків між елементами

3) In (innovations) - Визначення можливих інновацій та можливостей їх реалізації діяльності

4) Str (strategy) - Побудова стратегій та сценаріїв розвитку сфери

5) D (development) - Реалізація розроблених заходів на практиці 


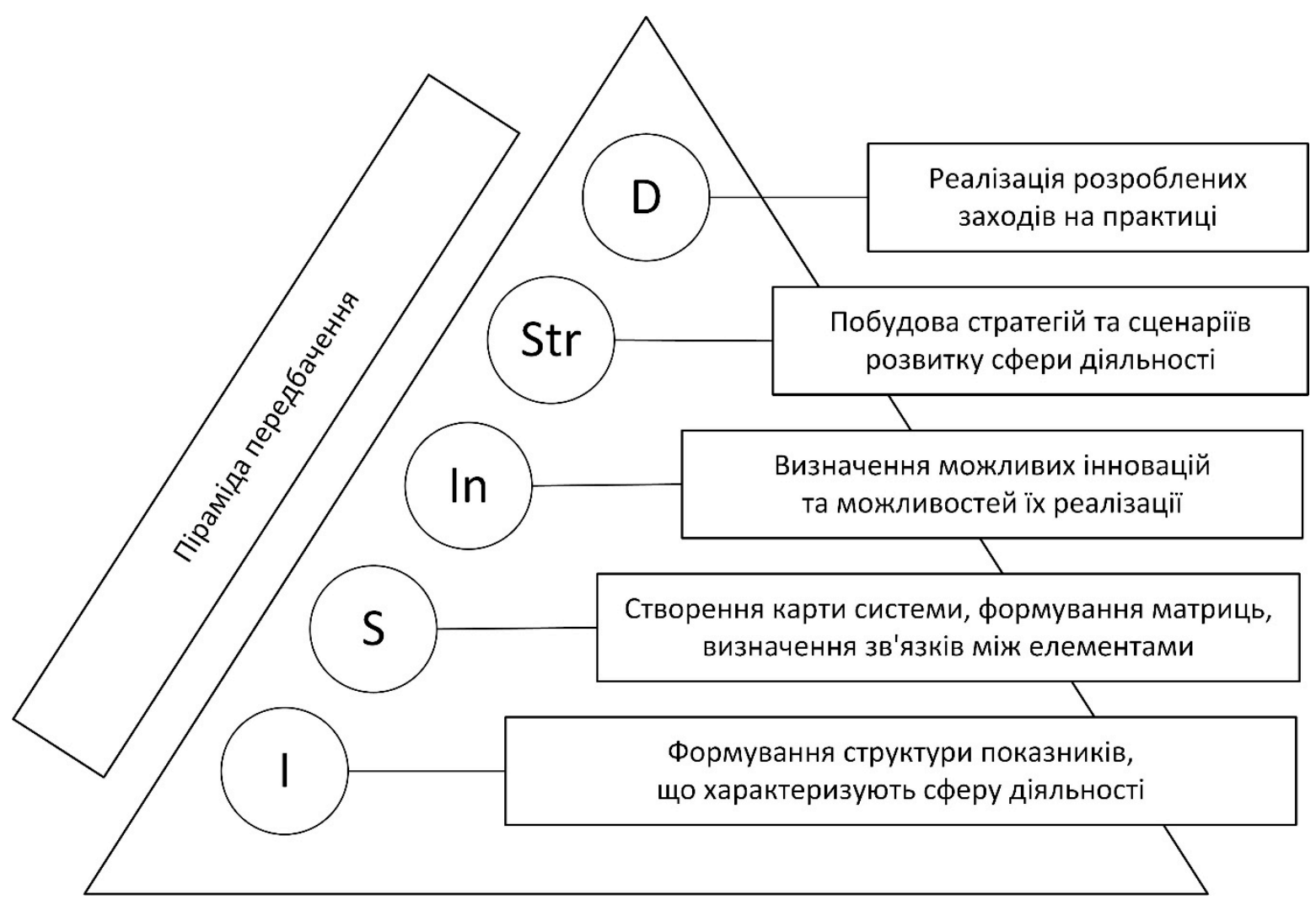

Рисунок. Піраміда комплексу робіт з передбачення

Комплекс вказаних робіт здійснюється шляхом виконання послідовності наступних кроків.

Крок 1. Формується група експертів, що є фахівцями як у промисловій сфері, так і в сферах економіки, екології, соціальної сфери.

Крок 2. Визначається мета та часові відтинки проведення Форсайту.

Крок 3. Формується основа піраміди (створюються таблиці числових значень показників, які характеризують сферу діяльності).

Крок 4. Створюється карти системи, формуються матриці, визначаються зв'язки між елементами (показуються у вигляді причинно-наслідкових діаграм).

Крок 5. На основі попереднього кроку визначається головний тренд, що впливає на розвиток сфери діяльності.

Крок 6. Визначаються можливість реалізації інновацій у сфері діяльності.

Крок 7. На базі аналізу інновацій, запропонованих експертами, 3 врахуванням аналітичної обробки даних (таблиці, матриці, зв'язки) формуються стратегії та сценарії.

Слід враховувати, що для значної кількості факторів варто враховувати обмеження для підприємств, які є на сьогодні і будуть на період розробки сценаріїв.

Висновки. Запропонований інструментарій методології Форсайту передбачає використання об'єктивних і суб'єктивних оцінок (експертиза) та методу Делфі. Положення методології дають можливість представити майбутнє, яке не може бути повною мірою інтерпретоване як звичайне 
продовження минулого, а з врахуванням суттєвих змін у техніці, технології, економіці чи у політиці.

Науковою новизною є методичний підхід до формування та використання інструментарію Форсайту для підприємств окремої галузі, який, на відміну від існуючих, надає можливість на основі методів Делфі (запропонована послідовність етапів), SWOT-аналізу із залученням експертів, а також процедур розробки сценаріїв розвитку на піраміди А. Аткіссона (комплекс робіт 3 передбачення) здійснити якісні передбачення

Подальших наукових досліджень потребує впровадження запропонованого методичного підходу для передбачення варіантів розвитку промислових підприємств (сценаріїв їх розвитку на довгострокову перспективу).

\section{Література:}

1. Згуровский М. 3. Системна методологія передбачення. К.: Політехніка, 2001, - 52 с.

2. Гапоненко Н. В. Форсайт. Теория. Методология. Опыт : монография / Н. В. Гапоненко. М. :Юнити-Дана, 2012. - 239 с.

3. Масленников В. В. Форсайт развития теории и технологии менеджмента: основы методологии : монография / В. В. Масленников, А. Н. Шмелева. - М. :Русайс, 2014 - 128 c.

4. Кваша Т.К. Проведение Форсайта и трансфера технологий в Украине / Т.К. Кваша, А.Л. Кушнир // Современные подходы взаимодействия ВУЗов с наукоемким бізнесом :материалы V Международного Форума От науки к бизнесу - СПб. - 2011.- С. 110-113.

5. Аткиссон А. Как устойчивое развитие может изменить мир / А. Аткиссон. - М. : БИНОМ. Лаборатория знаний, 2012. - 456 с. 